\title{
Why Are China and the U.S. Not Destined to Fall into the “Thucydides' Trap"?
}

\author{
Ling Shengli and \\ Lv Huiyi
}

\begin{abstract}
With the rise of China and relative decline of the United States, the question of whether both countries will fall into the so-called "Thucydides' Trap" — an analogy to the Peloponnesian War in ancient Greece - has triggered heated debate within international academia. By discussing the misunderstanding about the concept and conducting a three-level analysis of modern Sino-U.S. relations, this article identifies a few major flaws in making a simple analogy between the Athens-Sparta confrontation in ancient Greece and the Sino-U.S. relationship today. It concludes that a war between China and the United States is unlikely to take place thanks to the confines of the international system, the different
\end{abstract}

Ling Shengli is Associate Professor at the Institute of International Relations, China Foreign Affairs University (CFAU), and Secretary-General of the Center for International Security Studies, CFAU. His mailing address is: 24 Zhanlanguan Road, Xicheng District, Beijing 100037, China. He can also be reached at 2014004@cfau.edu.cn. Lv Huiyi is a graduate student from the Institute of International Relations, CFAU. She can be reached atlhycfau@163.com.

(c) 2018 World Century Publishing Corporation and Shanghai Institutes for International Studies China Quarterly of International Strategic Studies, Vol. 4, No. 4, 495-514

DOI: $10.1142 / S 2377740018500288$

This is an Open Access article, copyright owned by the SIIS and WCPC. The article is distributed under the Creative Commons Attribution 4.0 (CC BY-NC) Licence. Further distribution of this work is permitted, provided the original work is properly cited and for non-commercial purposes. 
nature of alliance networks from the ancient Greek period, the economic interdependence among countries, and the changing public attitude toward war. It also suggests both countries expand their economic, political, security and cultural cooperation, so as to ultimately overcome the "Thucydides' Trap."

Keywords: “Thucydides' Trap"; multi-level analysis; cause of war; Sino-U.S. relations.

\begin{abstract}
$\mathbf{W}_{\text {ith the lasting growth of China's comprehensive power, whether China }}$ and the United States will fall into the so-called "Thucydides' Trap," a concept coined by American scholar Graham Allison, has become a topic of global concern. However, it remains controversial as to whether the concept is truly relevant in the analysis of the Sino-U.S. relationship. To answer the question, one has to examine both the Peloponnesian War described by Thucydides and Sino-U.S. relations today, especially the roots of conflicts between the two major powers in both cases. Following a multi-level analytical approach, this article compares Athens and Sparta in the 5th century B.C. with China and the United States in the 21st century at the international, state and individual levels. In an effort to eliminate misunderstanding, this article will also analyze the problems pertinent to the concept and attempt to determine whether China and the United States are doomed to fall into the "Thucydides' Trap."
\end{abstract}

\title{
From Greece to the Asia-Pacific: The "Thucydides" Trap" as an Evolving Concept
}

Originated from ancient Greek historian Thucydides' portrayal of the Peloponnesian War between Athens and Sparta, the concept of the "Thucydides' Trap" was coined by American scholar Graham Allison in 2012 to describe the potential trends of Sino-U.S. relations. ${ }^{1}$ Since then, the concept has been often used in the interpretation of Sino-U.S. relations in the 21st century and has triggered much discussion within various social circles.

${ }^{1}$ Graham Allison, "Thucydides' Trap Has Been Sprung in the Pacific," Financial Times, August 21, 2012, https://www.ft.com/content/5d695b5a-ead3-11e1-984b-00144feab49a. 


\title{
Thucydides and the History of the Peloponnesian War
}

The Peloponnesian War took place from 431 to 404 B.C. between the Delos Alliance led by Athens and the Peloponnesian Alliance headed by Sparta, and Thucydides elaborated on the processes and causes of the war in his book, History of the Peloponnesian War. At the outset of the book, Thucydides offered two basic explanations to the war: the root cause and the direct reason. As he pointed out,

\begin{abstract}
All this came upon them with the late war, which was begun by the Athenians and Peloponnesians by the dissolution of the thirty years' truce made after the conquest of Euboea. To the question why they broke the treaty, I answer by placing first an account of their grounds of complaint and points of difference, that no one may ever have to ask the immediate cause which plunged the Hellenes into a war of such magnitude. The real cause I consider to be the one which was formally most kept out of sight. The growth of the power of Athens, and the alarm which this inspired in Lacedaemon, made war inevitable. ${ }^{2}$
\end{abstract}

Although Thucydides later interpreted the causes of the Peloponnesian War from many other angles, the ultimate cause of the war - "the rise of Athens and the fear inspired in Sparta" - has been recognized by a majority of political scientists and has evolved into the concept of the "Thucydides' Trap." Yet, whether Thucydides' interpretation has been oversimplified, and whether one can draw direct relations between China and the United States today with Athens and Sparta 24 centuries ago, are still open to question.

\section{Graham Allison and His Observation of Sino-U.S. Relations}

In his article "Thucydides' Trap Has Been Sprung in the Pacific" published in Financial Times in 2012, Harvard professor Graham Allison compared Sino-U.S. relations to Athens-Sparta relations during the ancient Greek period and defined the structural conflicts between rising and established

\footnotetext{
${ }^{2}$ Thucydides, History of the Peloponnesian War, Chap. 1, Vol. 1 (Cambridge: Harvard University Press, 1919).
} 
states as the "Thucydides" Trap." ${ }^{3}$ Later on, he published two other articles in the New York Times ${ }^{4}$ and The Atlantic ${ }^{5}$ to re-emphasize his "Thucydides' Trap" metaphor and its implications to Sino-U.S. relations.

In his latest book, Destined for War: Can America and China Escape Thucydides' Trap?, Professor Allison illustrates the relationship between the "Thucydides' Trap" and the causes of war between nations. He analyzed 16 cases similar to the "Thucydides' Trap" during the past 500 years, discovering that only four cases ended in a peaceful transition whilst the other 12 ended in the form of war. ${ }^{6}$ By comparing the basic conditions of the economic, political, cultural, and military aspects of the United States and China, he observes that the current Sino-U.S. relationship possesses all the characteristics of the "Thucydides' Trap," and thus concludes that there is a high possibility of war between both countries. ${ }^{7}$ Specifically, factors like cultural differences, cyber attacks, economic competition, the South China Sea disputes, the Korean Peninsula crises, and the Taiwan issue all present enormous challenges to future Sino-U.S. relations. ${ }^{8}$

Nevertheless, Professor Allison is not completely pessimistic. He believes that a war between China and the United States is not inevitable, as different strategic choices made by both countries will lead them into a different future. At the end of the book, he suggests U.S. leaders focus on addressing domestic challenges and enhance mutual understanding with their Chinese counterparts, for only in this way can China and the United States escape the "Thucydides' Trap."

${ }^{3}$ Graham Allison, "Thucydides's Trap Has Been Sprung in the Pacific."

${ }^{4}$ Graham Allison, "Obama and Xi Must Think Broadly to Avoid a Classic Trap," New York Times, June 7, 2013, https://www.nytimes.com/2013/06/07/opinion/obama-and-xi-mustthink-broadly-to-avoid-a-classic-trap.html.

${ }^{5}$ Graham Allison, “The Thucydides Trap: Are the U.S. and China Headed for War?,” The Atlantic, September 24, 2015, https://www.theatlantic.com/international/archive/2015/09/ united-states-china-war-thucydides-trap/406756/.

${ }^{6}$ Graham Allison, Destined for war: Can America and China Escape Thucydides' Trap? (New York: Houghton Mifflin Harcourt, 2017), pp. 27-89, and pp. 241-286.

${ }^{7}$ Ibid., pp. $1-4$.

${ }^{8}$ Ibid.

${ }^{9}$ Ibid., pp. 232-240. 


\section{Controversy over the "Thucydides' Trap"}

As the notion becomes ever more popular and has been mentioned often by top Chinese and American leaders, the "Thucydides' Trap" remains a topic of controversy within international academic and policy circles.

\section{The "Thucydides' Trap" remains a controversial term despite its popularity.}

Both Chinese and American government officials tend to hold an optimistic view that their countries can escape the “Thucydides' Trap." In 2014, Chinese President Xi Jinping stated that "we all need to work together to avoid the 'Thucydides' Trap."'10 In his speech in Seattle on September 24, 2015, he once again made it clear that " $[t]$ here is no such thing as the so-called Thucydides' trap in the world. But should major countries time and again make the mistakes of strategic miscalculation, they might create such traps for themselves." ${ }^{11}$ In response, then U.S. President Obama said in 2015 that he did not agree with the "Thucydides' Trap" notion and its relevance to U.S.-China relations. Although President Trump has not made a clear statement on whether there exists a "Thucydides' Trap" between China and the United States, he has many a time reiterated that both countries should maintain cooperation and manage their differences. During his meeting with President Xi at Mar-a-Lago in April 2017, President Trump said that the United States "is willing to further strengthen cooperation with China in economy, military affairs and people-to-people exchanges... ."12 He also said that "[i]n the coming months and years, I look forward to building an even stronger relationship between our two countries - China and the United States of America - and even closer friendships and relationships between the

10 “How the World's Most Powerful Leader Thinks," Huffington Post, January 21, 2014, http://www.huffingtonpost.com/2014/01/21/xi-jinping-davos_n_4639929.html.

11 "Full Text: President Xi's Speech on China-U.S. Ties," China Daily, September 24, 2015, http://www.chinadaily.com.cn/world/2015xivisitus/2015-09/24/content_21964069.htm.

${ }^{12}$ “Xi, Trump Pledge to Expand Mutually Beneficial Cooperation, Manage Differences," Xinhua News, April 8, 2017, http://www.xinhuanet.com/english/2017-04/08/c_136191678. htm. 
people of our countries."13 Obviously, neither the Chinese nor American top leader thinks their countries would fall into the "Thucydides' Trap."

In comparison, international scholars are more diversified on the concept. There are generally three views. The first view, mainly from Western and especially American scholars, is quite pessimistic. They believe that U.S.-China relations have fallen into or are about to enter the “Thucydides' Trap." For instance, in May 2015, American scholar David Lampton, who used to express much hope for a sound and lasting U.S.-China relationship, delivered a speech at the World Forum on China Studies, stating that "[a] tipping point in U.S.-China relations is upon us" and that " $[\mathrm{w}] \mathrm{e}$ are witnessing the erosion of some critical underlying supports for predominantly positive U.S.-China ties." ${ }^{14}$ Many other scholars, including some Chinese ones, tend to share this pessimistic observation. ${ }^{15}$

Most Chinese scholars, however, hold a different view that the "Thucydides' Trap" cannot be used to accurately describe Sino-U.S. relations. By dissecting the problems with the notion, they have sought ways for both countries to transcend the trap. For example, Professor Qin Yaqing finds that the Chinese philosophical model of "Yin and Yang Dialectics"

13“Remarks by President Trump and President Xi of China in Joint Press Statement," White House, November 9, 2017, https:/www.whitehouse.gov/briefings-statements/ remarks-president-trump-president-xi-china-joint-press-statement-beijing-china/.

${ }^{14}$ David Lampton, "A Tipping Point in U.S.-China Relations is Upon Us," US-China Perception Monitor, May 11, 2015, https://www.uscnpm.org/blog/2015/05/11/a-tippingpoint-in-u-s-china-relations-is-upon-us-part-i/.

${ }^{15}$ See, for example, Robert B. Zoellick, “U.S., China and Thucydides: How Can Washington and Beijing Avoid Typical Patterns of Distrust and Fear?," National Interest, June 25, 2013, https://nationalinterest.org/article/us-china-thucydides-8642;

Zbigniew Brzezinski, "Can China Avoid the Thucydides Trap?," New Perspectives Quarterly, Vol. 31. No. 2 (2014), pp. 31-33;

Zheng Yongnian, "Zhongmei Ruhe Bimian 'Xiuxidide Xianjing'? [How Can China and the United States Avoid the 'Thucydides Trap?']," Global Times, September 4, 2012, http:// opinion.huanqiu.com/1152/2012-09/3096922.html; Ye Zicheng, "Yi Zhonghua Zhihui Pojie 'Xiuxidide Xianjing' [Solving 'Thucydides Trap' with Chinese Wisdom]," People's Daily Online, March 20, 2014, http://politics.people.com.cn/n/2014/0320/c1001-24688470.html;

and Deng Yuwen, "Zhongmei Dieru 'Xiuxidide Xianjing' de Kenengxing Dazeng [Increasing Chances for China and the U.S. to Fall into 'Thucydides Trap']," Caijing News, February 4, 2017, http://yuanchuang.caijing.com.cn/2017/0204/4230447.shtml. 
is remarkably different from the Western thinking of "conflict and confrontation," and thus China's rise should be assessed from a holistic and historical perspective, instead of a zero-sum game. ${ }^{16}$ Professor Qian Shengdan pointed out directly that the "Thucydides' Trap" was inconsistent with historical facts and therefore may not apply to Sino-U.S. relations today. ${ }^{17}$ Some Western scholars also support this view. Henry Kissinger, for instance, asserts that there is no "Thucydides' Trap" between China and the United States unless people make it a "self-fulfilled prophesy." ${ }^{18}$ James Holmes, in his article "Beware the Thucydides Trap's Trap," argues that the Sino-U.S. relationship is very different from the Athenian-Spartan relationship in history and the Anglo-German relationship before World War I. ${ }^{19}$ Richard Lebow also disagrees with the inevitability of war between Athens and Sparta, pointing out that the Peloponnesian War could have been avoided had both sides exercised more empathy and thus adopted a milder stance. $^{20}$

Fostering a "new type of majorcountry relations" may be a good way to avoid the "Thucydides' Trap."

Rather than agreeing or disagreeing with the notion, the third point of view is focused on finding a substitute analogy to describe Sino-American relations. For instance, Professor Yan Xuetong proposes that the competition between China and the United States is "a football game rather than a boxing match," indicating that it is not necessarily a zero-sum game ending in a

\footnotetext{
${ }^{16}$ Qin Yaqing, "International Society as A Process of Relations - System, Identity and China's Peaceful Rise," Quarterly Journal of International Politic, No. 4 (2010), pp. 1-24.

${ }^{17}$ Qian Shengdan, "Bokai 'Xiuxidide Xianjing' Miwu [Seeing Through the Thick Fog of 'Thucydides Trap']," Cankaoxiaoxi.com, August 24, 2016, http://www.cankaoxiaoxi.com/ china/20160824/1279284.shtml.

${ }^{18}$ Henry Kissinger, On China (New York: Penguin Press, 2011), pp. 502-542.

${ }^{19}$ James Holmes, “Beware the Thucydides Trap's Trap: Why the U.S. and China Aren't Necessarily Athens and Sparta or Britain and Germany Before WWI," Diplomat, June 13, 2013, http://thediplomat.com/2013/06/beware-the-thucydides-trap-trap/.

${ }^{20}$ Richard Lebow, "Play It Again Pericles: Agents, Structure and the Peloponnesian War," European Journal of International Relations, Vol. 2, No. 2 (June 1996), p. 231.
} 
knockout. ${ }^{21}$ Indeed, the notion of "new type of major-country relations" has been applied more widely in recent years; both China and the United States are actually heading for a reciprocal relationship of "no conflict, no confrontation, mutual respect, and win-win cooperation" despite their current trade disputes and increasingly intense competition. ${ }^{22}$

These three views are all of great value to the study of the "Thucydides' Trap." Nevertheless, when using the concept, people tend to ignore Thucydides' multi-level analysis of the causes of the Peloponnesian War, which may lead to over-simplification or even misinterpretation of the Greek historian. This is because most of the existing discussion on this issue has taken only theory and reality into account, ${ }^{23}$ without looking into the specific historical context from which the Peloponnesian War originated. Thus, reexamining Thucydides' work may very well help us better understand the "Thucydides' Trap."

\section{Complex Causes of the Peloponnesian War}

The international academia tends to examine the causes of war at the international system level, hence concluding that war is often a result of the structural contradictions between established and rising powers. As a matter of fact, Thucydides conducted a multi-level (international system, state and individual) analysis of the complex causes of the war between Athens and Sparta in History of the Peloponnesian War.

${ }^{21}$ Yan Xuetong and Qi Haixia, “Football Game Rather Than Boxing Match: Intensifying China-U.S. Rivalry Does not Amount to Cold War," Chinese Journal of International Politics, Vol. 5, No. 2 (Summer 2012), pp. 105-127.

${ }^{22}$ Yuan Peng, "Some Strategic Thoughts on New Type China-U.S. Ties," Contemporary International Relations, No. 4 (2012), pp. 27-47;

Zhou Fangyin, "Toward a New Pattern of China-U.S. Relationship: Motives, Paths, and Prospects," Contemporary Asia-Pacific Studies, No. 2 (2013), pp. 4-21;

Yang Qinglong, "Toward a New Model of China-U.S. Relationship: From the Perspective of International Symbiosis Theory," Global Review, No. 1 (2017), pp. 109-125;

and $\mathrm{Wu}$ Xinbo, "Prospects for China-U.S. Relations under the Trump Administration," China International Studies, No. 3 (2017), pp. 45-62.

${ }^{23}$ Shi Yinhong, "Huaru Xiuxidide Xianjing de Quzhe Jianjin Zhilu: Gudianshidai Qishi [Sliding into the Thucydides Trap: A Classical Lesson for China-U.S. Relations]," The Paper, March 13, 2018, https://www.thepaper.cn/newsDetail_forward_2026039. 


\section{International System Level}

After the Greco-Persian Wars, Greece consisted of several city-states, and thus could be understood as a relatively independent international system, where the two major alliances headed by Athens and Sparta respectively were two major forces that determined the geopolitical dynamics of the system. Thucydides believed that both Athens and Sparta were responsible for the outbreak of the war. However, it is worth noting that in the early days of Athens' maritime power expansion, the two sides did make effort to resolve conflicts by diplomatic means. It was only after Athens had gained absolute maritime superiority that Sparta - as a dominant land power gave up the thirty-year peace pact and began to resort to force. ${ }^{24}$

With the shifting balance of power, Athens and Sparta could no longer rely on diplomatic means to settle their differences. The struggle for "strategic space" between the two city-states, especially Athens' severe punishment of and cruel attack on Sparta's allies, soon led the two powers into the "Thucydides' Trap" that ended in war. ${ }^{25}$ Therefore, it was not only the changes in the balance of power, but also the strategic interaction between both sides, that pushed them into war.

\section{State Level}

At the state level, alliance politics was an important factor in the political structure of Greece at that time, heavily influencing diplomatic behavior. After the Greco-Persian Wars, there emerged a "bipolar" system consisting of the Union of Tilos led by Athens and the Peloponnesian League headed by Sparta. Thucydides pointed out that the competition between the two alliances was an important reason for the outbreak of the Peloponnesian War. ${ }^{26}$ When Sparta's ally, Collins, was invaded by Athens, Sparta realized that Athens' expansion would undermine its alliance and break the regional balance. As diplomatic efforts proved futile in reining in Athens' behavior, Sparta chose to go to war. ${ }^{27}$

\footnotetext{
${ }^{24}$ Thucydides, History of the Peloponnesian War, Vol. I, p. 63.

${ }^{25}$ Shi, "Sliding into the Thucydides Trap: A Classical Lesson for China-U.S. Relations."

${ }^{26}$ Thucydides, History of the Peloponnesian War, Vol. I, pp. 25-26.

${ }^{27}$ Ibid., p. 61.
} 
Thus, the Peloponnesian War was not only caused by the rise of Athens and the growing panic of Sparta, but it was also due to the confrontation derived from the conflicts between Athens and Collins. Based on the theory of alliance, Sparta was in conflict with Athens because of its alliance with Collins. Since Athens and Sparta sat at the center of their respective alliances, an "alliance dilemma," where both sides could be drawn into unexpected confrontation due to factors regarding one of their allies, had consistently prevailed between these two city-states. In this sense, the strategic differences caused by the "alliance dilemma" had generated great impact on the outbreak of the war.

\section{Individual Level}

For the cause of the war at the individual level, the most important factor is the mentality of leaders, political elites and the public in both Athens and Sparta. Before the Peloponnesian War, neither leaders, political elites, nor the public, in both states showed a cautious attitude toward a potentially destructive outcome. In the name of safeguarding national dignity and honor, both leaders refused to make any compromise. ${ }^{28}$ As hostility escalated, the public in both states turned pessimistic and believed that a war was inevitable, thus becoming even more reluctant to seek alternative solutions to their conflicts. In the end, both the political elites and the public in the two states were inclined to resort to war.

Through Thucydides' analysis of the causes of the Peloponnesian War, it can be found that the widely adopted concept of "Thucydides' Trap" has two intrinsic problems. For one, it is based on the assumption that the cause of war is mainly at the international system level, while ignoring that war is usually a result of the interactions of multi-level factors; the oversimplified con-

The Peloponnesian War broke out for many reasons besides the shifting balance of power. cept neglects such important issues as how the conflicts between Athens and Collins transformed into acute confrontation between Athens and 
Sparta, and how the shifts in power balance between Athens and Sparta brought about the change in mentality and means of settling differences. For another, the concept's abstraction and generalization about the causes of the Peloponnesian War misinterprets the original intention of Thucydides, because it fails to explain why Sparta had waited in growing fear until Athens grew into an equally strong power. Without delving into historical context at the state and individual levels, it would be imprudent to judge the complex causes of the war.

\section{Sino-U.S. Competition: Will History Repeat Itself?}

This article does not intend to test the accuracy of Thucydides' account of history. Instead, in the context of the wide use of the "Thucydides' Trap" concept, this article aims to point out the possible flaws in the analogy of the Peloponnesian War to Sino-U.S. relations today. A core question is: will the historical tragedy of the ancient Greece repeat itself in the contemporary era? Put more simply, is a war inevitable between China and the United States? Following Thucydides, this article addresses the question from three distinct levels.

\section{International System Level}

As discussed previously, Thucydides believed that both Athens and Sparta should be responsible for the outbreak of the Peloponnesian War. He further pointed out that there were two prerequisites to this war: one was that Athens had grown into a more or less equal power to Sparta; the other was that the rapid rise of Athens triggered increasing panic in Sparta. These two preconditions, however, do not quite apply to the Sino-U.S. relationship today.

First of all, although China surpassed Japan as the world's secondlargest economy in 2010, there is still a large gap between China and the United States in terms of comprehensive power, which is difficult to bridge at least in the next one or two decades. Thucydides argued that when the gap of national strength is large, the established power is more inclined to use diplomatic means to resolve conflicts. The power shift theory of realism also points out that only when the rising country's power reaches 80 percent 
of the hegemonic power, will competition between them become more intense. $^{29}$

Despite the narrowing power gap between China and the United States in political, economic, cultural and social aspects, the disparity between them remains striking in terms of per capita income, military strength, education level, science and technology, and so on (Tables 1-4). Besides, the United States exercises nearly full dominance over the global commons and international strategic channels, extensive influence and decision-making power in international organizations, and the international cultural arenas. When China cannot challenge the U.S. predominant position in the world, the United States is very unlikely to provoke war on

Table 1. Economic Size.

\begin{tabular}{lcccc}
\hline Indicators & Country & 2000 & 2010 & 2016 \\
\hline GDP (\$ trillion) & China & 1.211 & 6.101 & 11.199 \\
& U.S. & 10.285 & 14.964 & 18.624 \\
& China/U.S. (percentage) & $12 \%$ & $41 \%$ & $60 \%$ \\
GDP per capita (\$) & China & 940 & 4,340 & 8,250 \\
& U.S. & 36,070 & 48,950 & 56,810 \\
& China/U.S. (percentage) & $3 \%$ & $9 \%$ & $15 \%$ \\
\hline
\end{tabular}

Table 2. Science \& Technology.

\begin{tabular}{lcccc}
\hline Indicators & Country & 2000 & 2010 & 2016 \\
\hline Publication of scientific papers & China & N/A & $316,915.3$ & $426,165.3$ \\
& U.S. & N/A & $409,853.3$ & $408,985.3$ \\
& China/U.S. (percentage) & N/A & $77 \%$ & $104 \%$ \\
Researchers in R\&D & China & 547.3 & 903 & 1176.6 \\
(per million people) & U.S. & 3475.7 & 3868.6 & 4232 \\
& China/U.S. (percentage) & $16 \%$ & $23 \%$ & $27 \%$ \\
R\&D expenditure (\% of GDP) & China & 0.896 & 1.71 & 2.066 \\
& U.S. & 2.617 & 2.734 & 2.794 \\
& China/U.S. (percentage) & $34 \%$ & $63 \%$ & $74 \%$ \\
\hline
\end{tabular}

${ }^{29}$ A.F.K. Organski and Jacek Kugler, The War Ledger (Chicago: University of Chicago Press, 1981), pp. 49-50. 
Table 3. Military Spending.

\begin{tabular}{lcccc}
\hline Indicators & Country & 2000 & 2010 & 2016 \\
\hline Military expenditure (\% of GDP) & China & N/A & 1.897 & 1.923 \\
& U.S. & 2.933 & 4.666 & 3.282 \\
& China/U.S. (percentage) & N/A & $41 \%$ & $59 \%$ \\
Armed forces personnel & China & 0.532 & 0.378 & 0.361 \\
(\% of total labor force) & U.S. & 0.991 & 0.999 & 0.838 \\
& China/U.S. (percentage) & $54 \%$ & $38 \%$ & $43 \%$ \\
\hline
\end{tabular}

Table 4. Social Resources.

\begin{tabular}{lcccc}
\hline Indicators & Country & 2000 & 2010 & 2016 \\
\hline Poverty headcount ratio at $\$ 1.90$ & China & 40.5 & 11.2 & 1.9 \\
$\quad$ or below a day (\% of population) & U.S. & 0.7 & 1 & 1 \\
& China/U.S. (percentage) & $5,786 \%$ & $1,120 \%$ & $190 \%$ \\
Enrollment of higher & China & 7.72 & 22.516 & 43.392 \\
education (\% of population) & U.S. & 64.186 & 94.288 & 85.796 \\
& China/U.S. (percentage) & $12 \%$ & $24 \%$ & $51 \%$ \\
\hline
\end{tabular}

Source: Compiled by the author based on data from the following websites: https://data. worldbank.org.cn/; http://www.lisdatacenter.org/; https://www.sipri.org/; http://www. wipo.int/portal/en/index.html; and http://uis.unesco.org/.

China, but rather seek comparatively more peaceful means - such as President Trump's aggressive economic measures - to rein in China's growth.

The American public views on potential

China threat are polarized.

Secondly, the American society in general does not fear the rise of China as much as often depicted in the media, but demonstrates a mentality intertwined with "containment" and "continuing engagement." According to a survey on the public's perception of the "biggest threat to the United States" conducted by the Pew Research Center in 2016, 80 percent of respondents chose the "Islamic State" (ISIS), followed by cyber-attacks (72 percent), economic turmoil (67 percent) and infectious diseases (60 percent), with only 50 percent choosing China's rise. As shown in Figure 1, the Pew survey also reflected a 


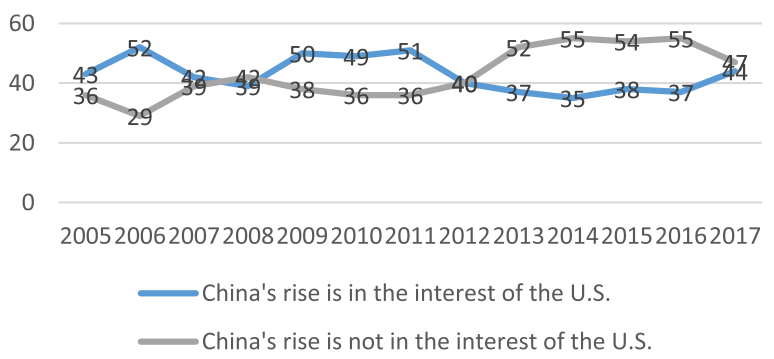

Fig. 1. U.S. Perception of China's Rise (2005-2017).

Source: "Americans' Views of China Improve as Economic Concerns Ease," Pew Research Center, April 4, 2017, http://www.pewglobal.org/2017/04/04/americans-views-of-china-improve-as-economicconcerns-ease/.

marked polarization of Americans' perceptions of China's rise over the past decade.

With regard to the rise of China, there are divergent views in the American academic and policy circles as to what policy the United States should adopt toward China. A growing number of people consider an ever stronger China as a major threat to the United States, and thus suggest different measures to check China's growing power and maintain the U.S. global leadership. For example, former U.S. Ambassador to India Robert Blackwill and Ashley Tellis, a researcher at Carnegie Endowment for International Peace, observe that China is and will be the top competitor for the United States for decades to come. ${ }^{30}$ Princeton University professor Aaron Friedberg compares China in the 21st century to the Soviet Union during the Cold War, believing that deep-rooted political and ideological differences between China and the United States will inevitably lead them to mutual distrust and competition. ${ }^{31}$ Professor John Mearsheimer, advocate of offensive realism, even asserts that China is more powerful and dangerous than any of the enemies the United States

${ }^{30}$ Robert Blackwill and Ashley Tellis, Revising U.S. Grand Strategy Toward China (New York: Council on Foreign Relations, April 2015), https://cfrd8-files.cfr.org/sites/default/files/ pdf/2015/04/China_CSR72.pdf.

${ }^{31}$ Aaron Friedberg, "The Future of U.S.-China Relations: Is Conflict Inevitable?," International Security, Vol. 30, No. 2 (Summer 2005), pp. 42-43. 
has fought in the 20th century, posing unprecedented challenges to the $\mathrm{U}$. S. national interest. ${ }^{32}$

Yet another view is that China and the United States can maintain a working relationship if the shifting power balance between them is well managed. For instance, Michael Swaine, a senior researcher at the Carnegie Endowment for International Peace, proposes that China and the United States work together to consolidate their relationship through a process of mutual accommodation. ${ }^{33}$ Dr. Henry Kissinger thinks that the danger of strategic competition between China and the United States is on the rise and thus both countries should adopt a "cooperative approach to exercise restraint." ${ }^{34}$ Rosemary Foot and Andrew Walter also call on both countries to engage each other more closely on international governance issues. ${ }^{35}$

The pluralistic thinking on the U.S. foreign policy helps to foster a relatively objective understanding of China, while the nuclear power status of both countries and their close economic ties tend to minimize the chance of military conflicts between them. From the perspective of the international system, it can be seen that China and the United States are significantly different from Athens and Sparta in history, and thus it is too early to say there exists a "Thucydides' Trap" between them.

\section{State Level}

As Thucydides described, the outbreak of the Peloponnesian War was closely related to alliance politics in Greece at that time. Similarly, the United States has maintained a strong alliance in the Asia-Pacific since the end of World War II; in recent years, the U.S. alliance and partnership network has been increasingly regarded as a strategic resource for its

${ }^{32}$ John Mearsheimer, The Tragedy of Great Power Politics (New York: W. W. Norton \& Company, 2001), p. 401.

${ }^{33}$ Michael Swaine, "Beyond American Predominance in the Western Pacific: The Need for a Stable U.S.-China Balance of Power," Contemporary American Review, Vol. 1, No. 2 (2017), pp. 61-77.

${ }^{34}$ Kissinger, On China, p. 542.

${ }^{35}$ Rosemary Foot and Andrew Walter, China, the United States, and Global Order (New York: Cambridge University Press, 2010), Chapters 3 and 14. 
competition with China in the region. ${ }^{36}$ The White House's 2017 National Security Strategy Report explicitly defines China as a "strategic rival" and advocates quadrilateral cooperation with Japan, India and Australia to manage potential challenges brought about by China's rise. ${ }^{37}$ Indeed, the U.S.' Asia-Pacific alliance has had great impact on the trends of Sino-U.S. relations.

However, the relationship between China and the United States as well as its allies in the era of globalization is completely different from that between Athens and Sparta in a rather fragmented city-state system and confrontational political environment in the 5th century B.C. For the past decade, the U.S.' allies and security partners in the Asia-Pacific have tended to adopt an ambivalent stance toward the United States and China: while trying to bandwagon with the former for more security guarantee, they rely on the latter's strong economic engine for more economic growth. They have generally adopted a dynamic balancing strategy to maximize their own interest and avoid being pulled into war due to the "alliance dilemma" as mentioned previously. ${ }^{38}$ In other words, although China and the United States are not free from the influence of alliance politics, the relationship between China and the U.S.' allies or security partners is very different from the two competing blocs of the ancient Greek period.

Notably, there are close economic and trade exchanges between China and the U.S.' allies and security partners. As of 2016, for example, China had become the largest trading partner with the United States' Asia-Pacific allies including South Korea, Thailand, the Philippines, Japan and Australia (Figure 2) - the first three are also

\section{The U.S. allies tend to play a buffering role between China and the U.S.}

${ }^{36}$ Ling Shengli, “China-U.S. Competition for Asia-Pacific Dominance: Cognitive Differences and Solutions," Journal of Social Sciences, No. 3 (2017), p. 20.

${ }^{37}$ White House, National Security Strategy 2017 (Washington, D.C., December 2017), http://nssarchive.us/wp-content/uploads/2017/12/2017.pdf.

${ }^{38}$ Ling Shengli, "Double Dilemma and Dynamic Balance: China-U.S. Contest for AsiaPacific Dominance and U.S. Asian Allies' Strategic Options," World Economics and Politics, No. 3 (2018), pp. 70-91. 


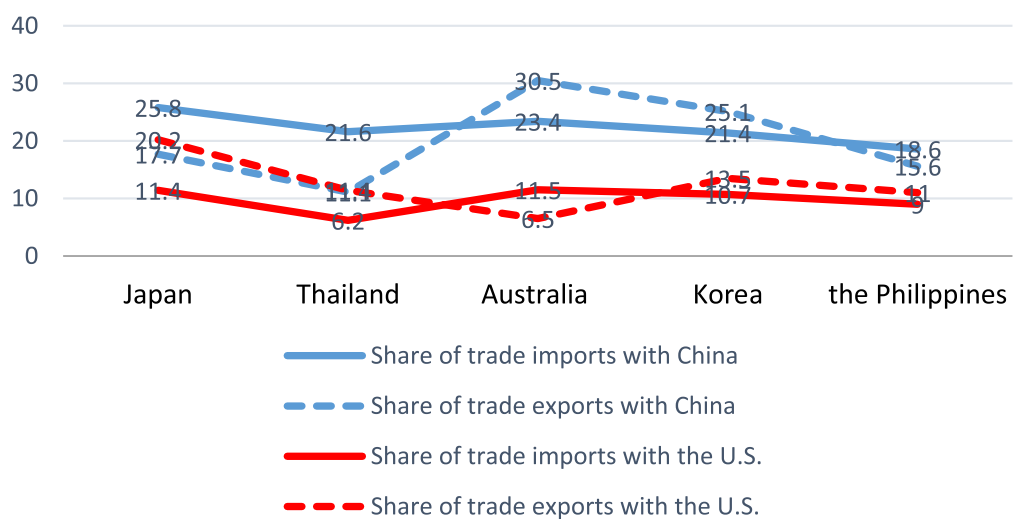

Fig. 2. Trade between U.S. Allies with the U.S. and China in 2016.

Source: CIA. https://www.cia.gov/library/publications/the-world-factbook/fields/2061.html.

active participants in China's "Belt and Road Initiative (BRI)" and Asian Infrastructure Investment Bank (AIIB) ${ }^{39}$ Highly interdependent relationships have, to a large extent, increased the cost of serious conflicts between countries. It means that it is in the interests of U.S. allies' and security partners for China and the United States to maintain mutually restrained competition rather than become embroiled in violent conflicts or even war. Therefore, these countries tend to play a buffering and moderating role between the two great powers, instead of a catalyst role like Collins that brought Athens and Sparta into the Peloponnesian War.

Besides, the U.S. allies have been working closely with China on various regional security institutions like dialogues, forums and other mechanisms. Since the end of the 20th century, the U.S.-centered bilateral alliance network and the multilateral cooperation network centered on the Association of Southeast Asian Nations (ASEAN) have developed and interwoven with each other. China has been enhancing its relations with AsiaPacific countries, including the U.S.' allies and security partners, on such platforms as the East Asian Summit (EAS), the ASEAN Regional Forum (ARF), and the Six-Party talks on the Korean Peninsula nuclear issue, which has not only strengthened their common understanding and empathy for each other, but also helped resolve disputes by peaceful means, thus greatly

${ }^{39}$ Refer to the BRI website: https://www.yidaiyilu.gov.cn/info/iList.jsp?cat_id=10037 \&cur_page $=2$. 
reducing the chance of violent conflicts between China and the United States as well as its allies.

\section{Individual Level}

At the individual level, Thucydides contended that the public's belief in the inevitability of war and the prevailing idea that state leaders ought to fight for national honor were largely responsible for the outbreak of the Peloponnesian War. Yet since the 1970s, war is much less frequently used to resolve disputes, especially among major powers. Having in memory the huge losses and casualties caused by the two world wars, the Korean War and the Vietnam War, the global public's common hope is for a stable international environment that would allow them to enjoy the benefits of economic development and improved living standards. Despite the growing anxiety about a rising China, the Gallup poll in 2017 indicates that half of Americans still hold a favorable opinion on China. ${ }^{40}$ It means that trade, people-to-people exchange and common development between China and the United States continue to serve as the foundation of peaceful relations between the two great powers.

From the perspective of leaders, neither China nor the United States is willing to bear the risks and consequences of war between them. A RAND report predicts that a Sino-U.S. war may result in a 5 to 10 percent drop in GDP and over 20 percent loss of military capacity of the United States, while China's loss would be much higher. ${ }^{41}$ Therefore, leaders of both countries have been seeking peaceful ways to resolve their disputes. As President $\mathrm{Xi}$ said, the Asia-Pacific should not become a

Peaceful coexistence and benign competition have become common sense in both China and the U.S.

40"Mindiao Xianshi Meiguoren Dui Zhongguo Haogandu Chuang Jin 30nianlai Xingao [Polls Show Record High American Favorable Attitude toward China in Three Decades]," Xinhua News, February 24, 2017, http://www.xinhuanet.com/world/2017-02/ 24/c_129495049.htm.

${ }^{41}$ David C. Gompert et al., War with China: Thinking Through the Unthinkable (Santa Monica, California: RAND, 2016). 
"wrestling ground," but a cooperative stage, for China and the United States. ${ }^{42}$ Chinese Foreign Minister Wang Yi also warned that any sensible statesman must admit that acute conflicts between China and the United States would be unbearable for both sides. ${ }^{43}$ In a similar vein, former U.S. President Obama stressed that the United States is firmly committed to building a mutually respectful and win-win partnership with China, and that the future of Sino-U.S. relations will not repeat the mistakes of history. ${ }^{44}$ Even U.S. Secretary of State Mike Pompeo, an acknowledged hardliner, does not see a "superpower conflict" between the U.S. and China as inevitable. ${ }^{45}$ Many people in the previous and current U.S. administrations openly suggest both countries make full use of their communication mechanisms to improve risk management, avoid misunderstanding and miscalculation, and seek pragmatic cooperation in more fields. ${ }^{46}$

Based on the above three-level analysis, the state and individual levels in particular, Sino-U.S. relations are significantly different from the relationship between Athens and Sparta before the Peloponnesian War. That means China and the United States are not doomed to war, but they can overcome the "Thucydides' Trap" through joint efforts.

\section{Conclusion}

This article analyzes the misunderstanding about the concept of the "Thucydides' Trap," clarifies Thucydides' multi-level explanation for the

42 “Interview with Chinese President Xi Jinping,” Wall Street Journal, September 22, 2015, https://www.wsj.com/articles/full-transcript-interview-with-chinese-president-xi-jinping-1442894700.

43 “Wang Yi Advises the US on the South China Sea Issue: Review the History of World War II," Chinese Embassy in the Commonwealth of Australia, February 8, 2017, http://au. china-embassy.org/eng//sghdxwfb_1/2017n/t1437328.htm.

44 “U.S. President Barack Obama Addresses the Opening Ceremony of the First ChinaU.S. Strategic and Economic Dialogue," Chinese Ministry of Commerce, May 18, 2012, http://english.mofcom.gov.cn/article/zt_forthsed/lanmuc/201205/20120508131774.shtml.

45 “Pompeo Voices Optimism for Good Outcome on U.S.-China Trade," Reuters, January 23, 2019, https://www.reuters.com/article/us-davos-meeting-pompeo-china/pompeovoices-optimism-for-good-outcome-on-u-s-china-trade-idUSKCN1PG25A.

${ }^{46}$ For example, see “Chinese Defense Minister Wei Fenghe Meets with Pentagon Chief Mattis," Xinhua News, November 10, 2018, http://www.xinhuanet.com/english/2018-11/10/ c_137596810.htm. 
Peloponnesian War, and points out the potential flaws in making a simple analogy between the Athens-Sparta confrontation in ancient Greece and the Sino-U.S. relationship today. According to the multi-level analysis of war elaborated by Thucydides, factors like the huge gap of comprehensive power between China and the United States, the close economic ties and security cooperation between China and U.S. allies, the flourishing cultural and people-to-people exchanges among all related countries, and the changing public attitude toward war, are all driving China and the United States to seek resolution to their disputes by peaceful means. War is no longer a viable option for both countries in formulating policy toward each other. To avoid war totally, however, China and the United States need to keep on strengthening their communication and crisis-management mechanisms and minimize the potential influence of third-party factors; more importantly, they need to enhance economic, political, security and cultural cooperation for lasting peace and common development. 